\title{
Myeloperoxidase Inhibition Decreases the Expression of Collagen and Metallopeptidase in Mare Endometria under In Vitro Conditions
}

\author{
Ana Amaral ${ }^{1}$ D , Carina Fernandes ${ }^{1}$, Maria Rosa Rebordão ${ }^{1,2}{ }^{\mathbb{D}}$, Anna Szóstek-Mioduchowska ${ }^{3}$, \\ Karolina Lukasik ${ }^{3}$, Pedro Pinto-Bravo ${ }^{2}$, Luís Telo da Gama ${ }^{1}$ (D), Dariusz Jan Skarzynski ${ }^{3}$ \\ and Graça Ferreira-Dias ${ }^{1, *(D)}$
}

1 CIISA-Centro de Investigação Interdisciplinar em Sanidade Animal, Departamento de Morfologia e Função, Faculdade de Medicina Veterinária, Universidade de Lisboa, 1300-477 Lisboa, Portugal; nita.amaral@gmail.com (A.A.); fachica@hotmail.com (C.F.); milorebordao@gmail.com (M.R.R.); ltgama@fmv.ulisboa.pt (L.T.d.G.)

2 Polytechnic of Coimbra, Coimbra Agriculture School, Bencanta, 3045-601 Coimbra, Portugal; pbravo@esac.pt 3 Institute of Animal Reproduction and Food Research, Polish Academy of Science, 10-748 Olsztyn, Poland; a.szostek-mioduchowska@pan.olsztyn.pl (A.S.-M.); k.lukasik@pan.olsztyn.pl (K.L.); d.skarzynski@pan.olsztyn.pl (D.J.S.)

* Correspondence: gmlfdias@fmv.ulisboa.pt; Tel.: +351-213-652-859

Citation: Amaral, A.; Fernandes, C.; Rebordão, M.R.;

Szóstek-Mioduchowska, A.; Lukasik, K.; Pinto-Bravo, P.; Telo da Gama, L.; Jan Skarzynski, D.; Ferreira-Dias, G. Myeloperoxidase Inhibition

Decreases the Expression of Collagen and Metallopeptidase in Mare Endometria under In Vitro Conditions. Animals 2021, 11, 208. https://doi.org/10.3390/ani11010208

Received: 23 November 2020 Accepted: 14 January 2021 Published: 16 January 2021

Publisher's Note: MDPI stays neutral with regard to jurisdictional clai$\mathrm{ms}$ in published maps and institutional affiliations.

Copyright: $\odot 2021$ by the authors. Licensee MDPI, Basel, Switzerland. This article is an open access article distributed under the terms and conditions of the Creative Commons Attribution (CC BY) license (https:// creativecommons.org/licenses/by/ $4.0 /)$.
Simple Summary: Myeloperoxidase, which is released by neutrophils when they form neutrophil extracellular traps, has already been related to equine endometrosis development. The myeloperoxidase inhibitor 4-aminobenzoic acid hydrazide (ABAH) has shown promising results inhibiting myeloperoxidase in other pathological conditions. The metallopeptidases (MMP-2/-9) regulates the extracellular matrix turnover. In the present study, in equine explants from follicular phase, myeloperoxidase treatment increased collagen type I relative protein abundance, but the use of ABAH reduced it. In mid-luteal phase endometrial explants, MMP-2 seems to be implicated in an acute reaction to myeloperoxidase treatment, while in the follicular phase, MMP-9 might be associated with a prolonged exposition to myeloperoxidase. The impairment of equine endometrosis can be achieved by inhibiting the pro-fibrotic effects of myeloperoxidase using the inhibitor ABAH.

Abstract: Neutrophils can originate neutrophil extracellular traps (NETs). Myeloperoxidase (MPO) is a peroxidase found in NETs associated to equine endometrosis and can be inhibited by 4-aminobenzoic acid hydrazide (ABAH). Metallopeptidases (MMPs) participate in extracellular matrix stability and fibrosis development. The objectives of this in vitro work were to investigate, in explants of mare's endometrium, (i) the ABAH capacity to inhibit MPO-induced collagen type I (COL1) expression; and (ii) the action of MPO and ABAH on the expression and gelatinolytic activity of MMP-2/-9. Explants retrieved from the endometrium of mares in follicular or mid-luteal phases were treated with MPO, ABAH, or their combination, for 24 or $48 \mathrm{~h}$. The qPCR analysis measured the transcription of COL1A2, MMP2, and MMP9. Western blot and zymography were performed to evaluate COL1 protein relative abundance and gelatinolytic activity of MMP-2/-9, respectively. Myeloperoxidase elevated COL1 relative protein abundance at both treatment times in follicular phase $(p<0.05)$. The capacity of ABAH to inhibit MPO-induced COL1 was detected in follicular phase at $48 \mathrm{~h}(p<0.05)$. The gelatinolytic activity of activated MMP-2 augmented in mid-luteal phase at $24 \mathrm{~h}$ after MPO treatment, but it was reduced with $\mathrm{MPO}+\mathrm{ABAH}$ treatment. The activity of MMP-9 active form augmented in MPO-treated explants. However, this effect was inhibited by ABAH in the follicular phase at $48 \mathrm{~h}(p<0.05)$. By inhibiting the pro-fibrotic effects of MPO, it might be possible to reduce the development of endometrosis. Metallopeptidase- 2 might be involved in an acute response to MPO in the mid-luteal phase, while MMP-9 might be implicated in a prolonged exposition to MPO in the follicular phase.

Keywords: endometrosis; myeloperoxidase; 4-aminobenzoic acid hydrazide; fibrosis; metallopeptidases 


\section{Introduction}

Myeloperoxidase (MPO) is an enzyme that is expressed by several immune cells, such as neutrophils, monocytes, and macrophages [1,2]. Neutrophils are the first leucocytes acting on the defense against microbial attacks $[3,4]$ and are able to degranulate and release their DNA and some enzymes that possess antimicrobial properties. Thus, they form neutrophil extracellular traps (NETs). Some proteases, such as cathepsin G and elastase, and the peroxidase MPO are released by NETs to fight bacteria [5]. Among these enzymes, MPO has been described to be the most abundant one in neutrophils [6]. It uses the bacteria-induced hydrogen peroxide to produce chloramine and hypochlorite, which are toxic products for bacteria [3,7].

After mating or artificial insemination, the sperm induces inflammation with a rapid influx of neutrophils into the uterus, which in turn leads to a physiological transient breeding-induced endometritis $[8,9]$. This inflammatory response results in the elimination of needless spermatozoa, contaminating bacteria, and debris introduced in the uterus $[10,11]$. The process of NETs formation in equine endometrium has already been demonstrated by the contact of equine neutrophils with semen $[12,13]$ or with bacteria associated with endometritis [14]. However, besides the antimicrobial properties of NETs components, they may also contribute to the development of some pathological conditions [15]. High concentrations of MPO in uterine lavage of mares was already related with endometritis [16], even though this was not demonstrated in cows with endometritis [17]. In our previous studies, we have also identified the involvement of NETs proteases in the establishment of endometrosis [18-21]. Endometrosis is a fibrotic, progressive, and degenerative condition, mainly diagnosed on the grounds of the paramount pathologic deposition of extracellular matrix (ECM) proteins, such as collagen, in mare endometrium [22,23]. In fact, the treatment of equine endometrial explants with NETs proteases induced collagen type I (COL1) expression [18-21]. In humans, elevated levels of MPO in cystic fibrosis sputum have been associated with the severity of lung disease [24,25]. Moreover, this enzyme has also been linked to liver fibrosis [26,27].

The 4-aminobenzoic acid hydrazide (ABAH), among many MPO inhibitors tested, has been the most investigated $[28,29]$. Recent studies have shown that ABAH reduced MPO-dependent mice hepatocyte death [27], decreased the activity of MPO in acute stroke in mice [30], and inhibited MPO in cystic fibrosis sputum in humans [31].

Metallopeptidases (MMPs) are a group of enzymes that mediate ECM turnover. Metallopeptidase-2 and -9 are endopeptidases that denature ECM substrates, such as collagens (gelatins) [32]. In addition, the expression and activity of MMPs are affected by ovarian hormones in human endometrial tissue remodeling during the estrous cycle phases [33], but their role in fibrosis establishment is still uncertain. Comparing the normal and fibrotic equine endometrium, Aresu et al. [34] found no alteration in MMP-2/-9 expression. However, MMP-2 transcription [35] and its active form [36] were up-regulated in mare endometrosis. Our latest in vitro studies in equine endometrium revealed that the expression of MMPs is altered by factors involved in inflammation [transforming growth factor (TGF) $\beta 1$, interleukins and prostaglandins] [37-39], and could contribute to the fibrotic response to elastase [20] and cathepsin G [21].

Taking into consideration that equine endometrial explants treated with enzymes found in NETs induced COL1, it could be proposed that NETs enzymes play a role in equine endometrial fibrosis establishment. Thus, the rationale was to investigate if inhibiting NETs enzymes would reduce the MPO induced COL1. This way, we proposed to evaluate if a selective inhibitor of NETs enzyme MPO would be effective in reducing MPO pro-fibrotic effect, as it has been shown in other organs and species. Our previous in vitro findings in mare endometrial explants showed that COL1 induced by elastase and cathepsin G was reduced by the use of their selective inhibitors $[20,21]$. We have hypothesized that by inhibiting MPO, the in vitro production of COL1 by mare endometrial explants would be reduced. Thus, the objectives of this in vitro work were to investigate, in explants of mares' endometrium, (i) the ABAH capacity to inhibit MPO-induced collagen type I (COL1) 
expression; and (ii) the action of MPO and $\mathrm{ABAH}$ on the expression and gelatinolytic activity of MMP-2/-9.

\section{Materials and Methods}

\subsection{Mares and Retrieval of Endometrium}

Uteri from cyclic mares $(n=14)$ intended for meat production were collected postmortem at an abattoir (Rawicz, Poland) within 10-15 min of the mares' euthanasia, in agreement the European (EFSA, AHAW/04-027) legislation. As confirmed by the inspection carried out by the official veterinary doctor, the mares used in this study showed no signs of illness. For further progesterone (P4) analysis, blood from the jugular vein was withdrawn into ethylenediaminetetraacetic acid (EDTA) tubes. For each mare, the estrous cycle phase was determined according to uterine and ovarian evaluation and confirmed by P4 concentration in plasma [18,40]. For this study, mid-luteal phase (MLP; $n=6$ ) and follicular phase (FP; $n=8$ ) endometria were immediately transported on ice to the laboratory. As previously reported, mare uteri were placed in ice-cold Dulbecco's modified Eagle's medium (DMEM) F-12 Ham medium (D/F medium; 1:1 (v/v); D-2960; Sigma-Aldrich, St Louis, MO, USA), supplemented with $100 \mu \mathrm{g} / \mathrm{mL}$ streptomycin (S9137; Sigma-Aldrich), $100 \mathrm{IU} / \mathrm{mL}$ penicillin (P3032; Sigma-Aldrich) and $2 \mu \mathrm{g} / \mathrm{mL}$ amphotericin (A2942; Sigma-Aldrich). Only endometria without endometritis were included in the study, as previously referred $[18,41]$. After samples were collected, two pieces of endometrium were immersed in $4 \%$ buffered paraformaldehyde for the histopathological classification of the endometrium [42]. The endometrial samples were classified as I, IIA, IIB, or III categories based on the extent of inflammation and/or fibrosis, according to Kenney and Doig [42]. Only mares presenting mild to moderate histopathological lesions (IIA or IIB category) were considered in this experiment to exclude the variation that is due to endometrial fibrotic grade.

\subsection{In Vitro Culture of Endometrial Explants}

Endometrial explants preparation and culture were performed as reported before [20]. The explants were pre-incubated for $1 \mathrm{~h}$ at $38{ }^{\circ} \mathrm{C}, 5 \% \mathrm{CO}_{2}$, in a chamber with a humidified atmosphere (Biosafe Eco-Integra Biosciences, Chur, Switzerland) in 24-well cell culture sterile plates (Eppendorf, \#0030 722.116) with $1 \mathrm{~mL}$ of DMEM culture medium supplemented with $0.1 \%(w / v)$ bovine serum albumin (BSA; 735078; Roche Diagnostics, Mannheim, Germany), 2 g/mL amphotericin (A2942; Sigma-Aldrich), $100 \mathrm{IU} / \mathrm{mL}$ penicillin (P3032; Sigma-Aldrich), and $100 \mu \mathrm{g} / \mathrm{mL}$ streptomycin (S9137; Sigma-Aldrich) with gentle shaking (150 rpm). Afterwards, endometrial explants (FP: $n=8$; MLP: $n=6$ for all the performed treatments) were further treated in new culture medium for $24 \mathrm{~h}$ or $48 \mathrm{~h}$ with (i) vehicle (negative control)-culture medium alone; (ii) myeloperoxidase (MPO; $0.5 \mu \mathrm{g} / \mathrm{mL}$; orb81997; Biorbyt, Cambridge, UK); (iii) 4-aminobenzoic hydrazide, an MPO inhibitor (ABAH; $10 \mu \mathrm{g} / \mathrm{mL}$; C7H9N3O, sc-204107; Santa Cruz Biotechnology, Dallas, TX, USA); (iv) MPO $(0.5 \mu \mathrm{g} / \mathrm{mL})+$ ABAH $(10 \mu \mathrm{g} / \mathrm{mL})$; or (v) oxytocin (OXT; 10-7 M). Oxytocin was previously used to induce prostaglandin (PG) secretion in equine endometrial explants [43,44]. Thus, in the present study, OXT treatment was a means to determine explant viability by assessing endometrium in vitro capacity to secrete PGF2 $\alpha$ throughout the incubation time. A fibrogenic assay using TGF $\beta 1$ was previously carried out as a positive control for COL expression [20]. Each treatment was carried out in quadruplicate. When the culture media were replaced, $1 \mathrm{~h}$ after pre-incubation, ABAH was added. One hour later, MPO was added to allow binding of the inhibitor. In studies lasting for $48 \mathrm{~h}, 10 \mu \mathrm{g} / \mathrm{mL}$ of $\mathrm{ABAH}$ were furthered added after the first $24 \mathrm{~h}$ of treatment since in the pre-trial its inhibitory effect persisted only for $24 \mathrm{~h}$ and subsided afterwards. In the end, explants (in RNAlater, R901, Sigma-Aldrich) and conditioned culture media were stored at $-80^{\circ} \mathrm{C}$. For PG analysis, a 1\% stabilizer solution of 0.3M EDTA (E5134, Sigma-Aldrich) and 1\% aspirin (A2093; Sigma-Aldrich) was added to the culture medium to prevent degradation before storage at $-80{ }^{\circ} \mathrm{C}$. 
The expression of TGF $\beta 1$, as a fibrotic indicator [18], was induced by $0.5 \mu \mathrm{g} / \mathrm{mL}$ of MPO in a dose assessment assay. In addition, a dose-response trial based in other in vitro studies [28,45], using $0.01,0.1,1,10$ and $100 \mu \mathrm{g} / \mathrm{mL}$ of $\mathrm{ABAH}$, showed that the optimum concentration that inhibited COL1A2 mRNA MPO-induced was $10 \mu \mathrm{g} / \mathrm{mL}$ (data not shown).

\subsection{Endometrial Explant Viability Assay}

The endometrial explant viability was evaluated by lactate dehydrogenase (LDH) activity and by PGF $2 \alpha$ secretion in conditioned culture medium, as described [20]. The data of viability of endometrial explants are presented in Supplementary Material, Figures S1 and S2.

\subsection{Total RNA Extraction, Synthesis of $c D N A$ and $q P C R$}

TRI Reagent ${ }^{\circledR}$ (T9424; Sigma-Aldrich) was used to perform the extraction of total RNA, following the guidelines provided by the manufacturer. The evaluation of both RNA quality and quantity, as well as cDNA synthesis, was done as already reported [20]. The primer sequences for COL1A2, MMP2, MMP9, and for ribosomal protein L32 (RPL32) reference gene were earlier determined (Table 1), as well as the reference gene validation [20,46]. The reference genes tested were glyceraldehyde 3-phosphate dehydrogenase (GAPDH), succinate dehydrogenase A complex, subunit A, flavoprotein (SDHA), beta-2-microglobulin (B2M), and RPL32. The RPL32 reference gene was revealed to be the most stable among the genes tested, showing less than two-fold changes between different biological conditions [46]. The target and reference gene reactions were run simultaneously, in duplicate, on a 96 well plate (4306737; Applied Biosystems) and run in a StepOnePlus ${ }^{\text {TM }}$ Real-Time PCR System (Applied Biosystems, Warrington, UK). The specificity of the qPCR products was performed as described $[20,47]$.

Table 1. List of primers utilized in quantitative real-time polymerase chain reaction (qPCR).

\begin{tabular}{|c|c|c|}
\hline $\begin{array}{c}\text { Gene } \\
\text { (Accession Number) }\end{array}$ & Sequence $5^{\prime}-3^{\prime}$ & Amplicon \\
\hline \multirow{2}{*}{$\begin{array}{c}R P L 32 \\
(\mathrm{XM}+001492042.6)\end{array}$} & Forward: AGCCATCTACTCGGCGTCA & \multirow{2}{*}{144} \\
\hline & Reverse: GTCAATGCCTCTGGGTTTCC & \\
\hline \multirow{2}{*}{$\begin{array}{c}\text { COL1A2 } \\
\left(\mathrm{XM} \_001492939.3\right)\end{array}$} & Forward: CAAGGGCATTAGGGGACACA & \multirow{2}{*}{196} \\
\hline & Reverse: ACCCACACTTCCATCGCTTC & \\
\hline \multirow{2}{*}{$\begin{array}{c}\text { MMP2 } \\
(\mathrm{XM}=001493281.2)\end{array}$} & Forward: TCCCACTTTGATGACGACGA & \multirow{2}{*}{115} \\
\hline & Reverse: TTGCCGTTGAAGAGGAAAGG & \\
\hline \multirow{2}{*}{$\begin{array}{c}\text { MMP9 } \\
\text { (NM_001111302.1) }\end{array}$} & Forward: GCGGTAAGGTGCTGCTGTTC & \multirow{2}{*}{177} \\
\hline & Reverse: GAAGCGGTCCTGGGAGAAGT & \\
\hline
\end{tabular}

\subsection{Western Blot Analysis}

Equine endometrial explants were processed as described before [20]. Collagen type I protein relative abundance was determined by the non-staining total protein loading control method, as reported before [20]. The primary against COL1 antibody (1:1000 diluted; 20121; Novotec, Lyon, France) was incubated overnight at $4{ }^{\circ} \mathrm{C}$, as previously described, and validated [18]. The secondary antibody utilized was Horseradish peroxidase (HRP)-conjugated anti-rabbit (1:20,000; P0448; DakoCytomation, Carpinteria, CA, USA) incubated for $1.5 \mathrm{~h}$ at room temperature. Imaging of relative protein abundance of COL1 was achieved by luminol-enhanced chemiluminescence (Super Signal West Pico, 34077; Thermo Scientific, Waltham, MA, USA). For band normalization and comparison of all membranes, a standard sample $(30 \mu \mathrm{g})$ of a mix of explants was loaded in all gels. Image Lab 6.0 (Bio-Rad, Hercules, CA, USA) software and a multichannel protocol were used to 
analyze COL1 relative abundance in lanes in non-staining total protein membrane image. After antibodies incubation, the band was detected on chemiluminescence image. The target protein volume was software-calculated using a normalization factor allowing the adjustment of variability of the protein loaded [20,48].

\subsection{Zymography}

The MMP-2 and MMP-9 gelatinolytic activity was assessed by zymography, as described before [49]. Normalization of zymograms was accomplished using a non-staining total protein loading control [50]. The explant culture supernatant was processed, as described [20]. The molecular weight determination was made using Recombinant Human MMP-2 Protein, CF (902-MP-010; R\&D Systems, Minneapolis, MN, USA), and Recombinant Human MMP-9 Western Blot Standard Protein (WBC018; R\&D Systems). To relate all the gels, a single lane of $40 \mu \mathrm{g}$ standard sample of a mix of culture media was loaded. A multichannel protocol (Image Lab 6.0, Bio-Rad) was created for the detection of lanes in non-staining total protein gel image and bands on Coomassie staining image. Volume of target protein as well as the normalization factor were calculated and the values adjusted for protein load variation $[20,50]$.

\subsection{Statistical Analysis}

Data normality was evaluated visually and by the Kolmogorov-Smirnov test in Proc Univariate of SAS v. 9.4 (SAS Institute Inc., Cary, NC, USA). The viability data were assessed by one-way analysis of variance (ANOVA) followed by Tukey's multiple comparisons test (GraphPAD PRISM, Version 6.00, 253 GraphPad Software, San Diego, CA, USA). These results are displayed as mean $\pm \mathrm{SEM}$, and significance was determined at $p<0.05$. The evaluated variables consisted of COL1A2, MMP2 and MMP9 transcription; relative COL1 protein abundance; and gelatinolytic activity of MMP-2/-9. Since some variables did not present a normal distribution, the square root and logarithmic transformation were used to transform these data for further analysis. In the first analysis, the PROC GLM of SAS was used to analyze each response variable to different treatments, including combination of the effect of $\mathrm{MPO}$, the use of $\mathrm{ABAH}$, estrous cycle phase, and time of treatment, resulting in 16 treatment combinations in total. The least square means of the treatment combinations were compared (using the PDIFF of PROC GLM), and results were significant at $p<0.05$. To perform the graphical presentation, the means were back transformed. After, the two-, three-, and four-way interactions were also analyzed.

\section{Results}

\subsection{The Effect of ABAH on the Inhibition of COL1 Induced by MPO}

In Figure 1, the relative mRNA transcription and protein abundance of COL1 results are presented as median with interquartile range. Likewise, in Figure 2, the transcription of $M M P 2 / 9$ is shown as median with interquartile range. However, in Figure 3, the results of MMP-2/-9 gelatinolytic activities are presented as least square means \pm SEM. These figures were drawn in GraphPAD PRISM. 

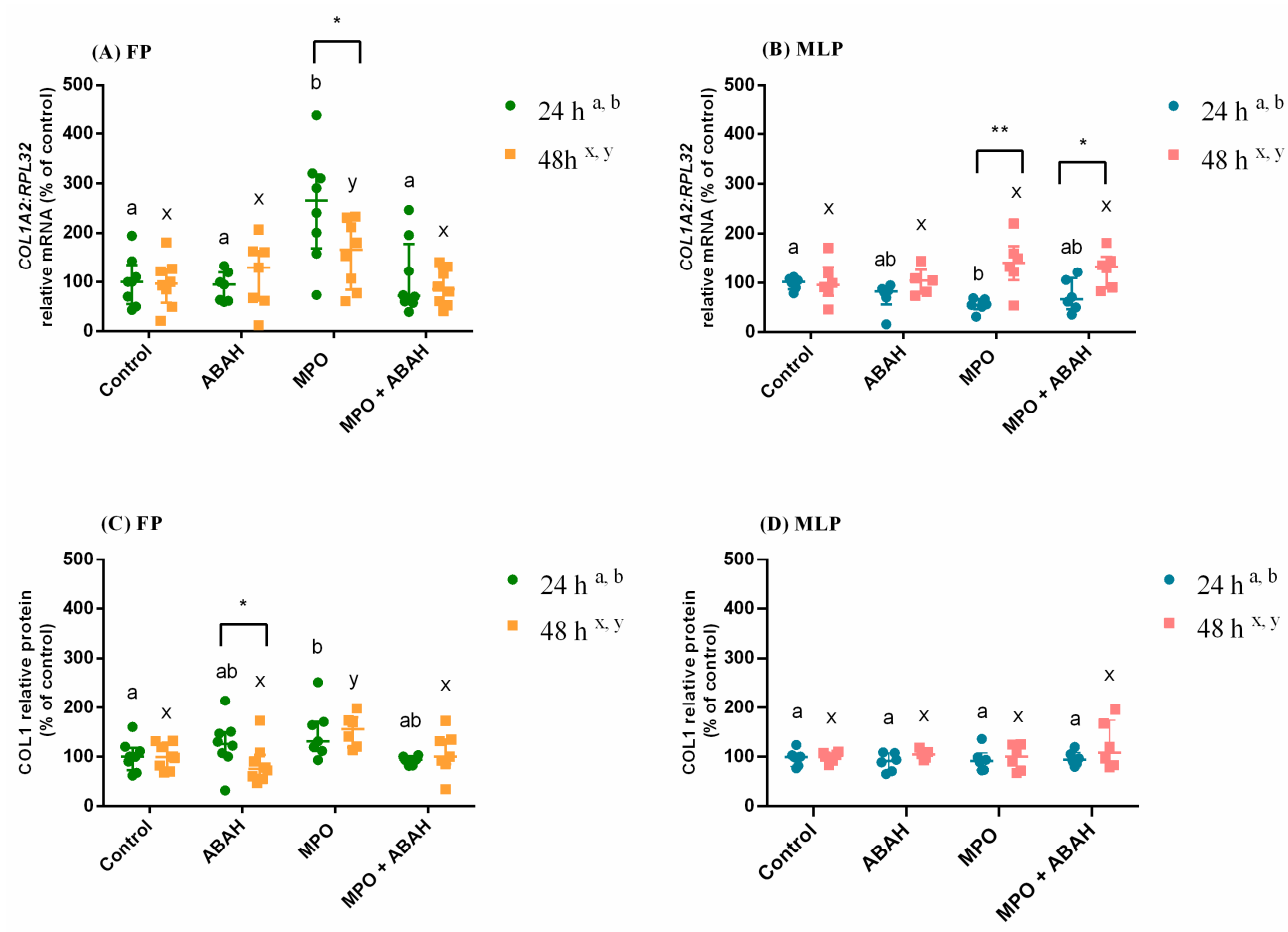

Figure 1. Relative mRNA transcription of type I collagen $(C O L 1 A 2)(\mathbf{A}, \mathbf{B})$ and relative abundance of COL1 protein $(\mathbf{C}, \mathbf{D})$ in mare endometrial explants from the follicular phase (FP) and the mid-luteal phase (MLP) treated with culture medium only (Control), myeloperoxidase (MPO: $0.5 \mu \mathrm{g} / \mathrm{mL}$ ), 4-aminobenzoic hydrazide (ABAH: $10 \mu \mathrm{g} / \mathrm{mL})$, or MPO $(0.5 \mu \mathrm{g} / \mathrm{mL})+\mathrm{ABAH}$ $(10 \mu \mathrm{g} / \mathrm{mL})$ for 24 or $48 \mathrm{~h}$. Results are presented as median with interquartile range. Significance was determined at $p<0.05$. The differences among treatments with the same treatment time are signaled by distinct superscript letters $(\mathrm{a}, \mathrm{b}-24 \mathrm{~h} ; \mathrm{x}, \mathrm{y}-48 \mathrm{~h})$. The differences among times of treatment for the identical treatment are shown by asterisks $\left.{ }^{*} p<0.05 ;{ }^{* *} p<0.01\right)$.
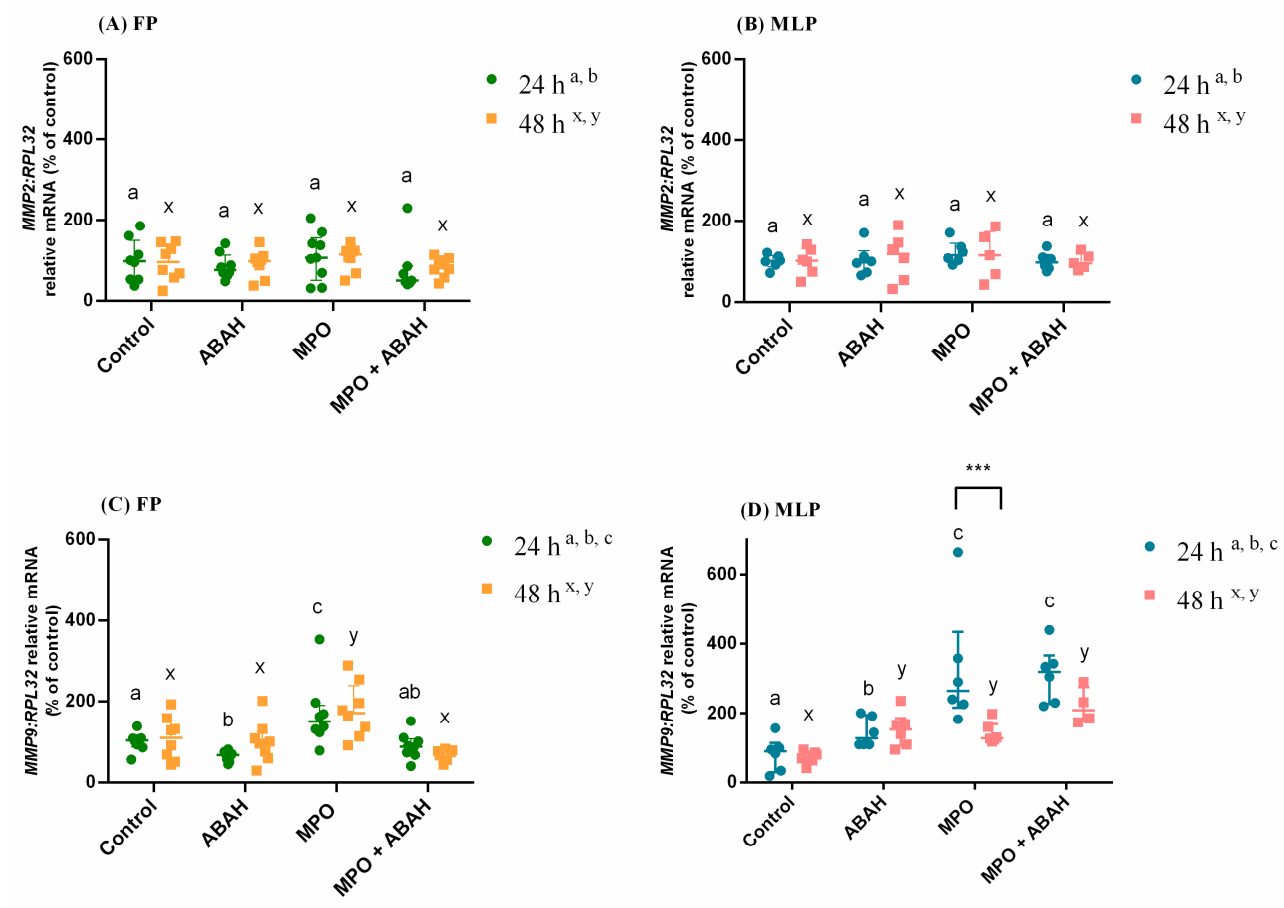

Figure 2. Transcription of $M M P 2(\mathbf{A}, \mathbf{B})$ and $M M P 9(\mathbf{C}, \mathbf{D})$ relative mRNA in mare endometrial explants from the follicular phase (FP) and the mid-luteal phase (MLP) treated with culture medium only (Control), myeloperoxidase (MPO: $0.5 \mu \mathrm{g} / \mathrm{mL}$ ), 4-aminobenzoic hydrazide (ABAH: $10 \mu \mathrm{g} / \mathrm{mL})$, or MPO $(0.5 \mu \mathrm{g} / \mathrm{mL})+\mathrm{ABAH}(10 \mu \mathrm{g} / \mathrm{mL})$ for 24 or $48 \mathrm{~h}$. Results are presented as median with interquartile range. Significance was determined at $p<0.05$. The differences among treatments with the same treatment time are signaled by distinct superscript letters $(a, b, c-24 h ; x, y-48 h)$. The differences among times of treatment for the identical treatment are depicted by asterisks (*** $p<0.001$ ). 


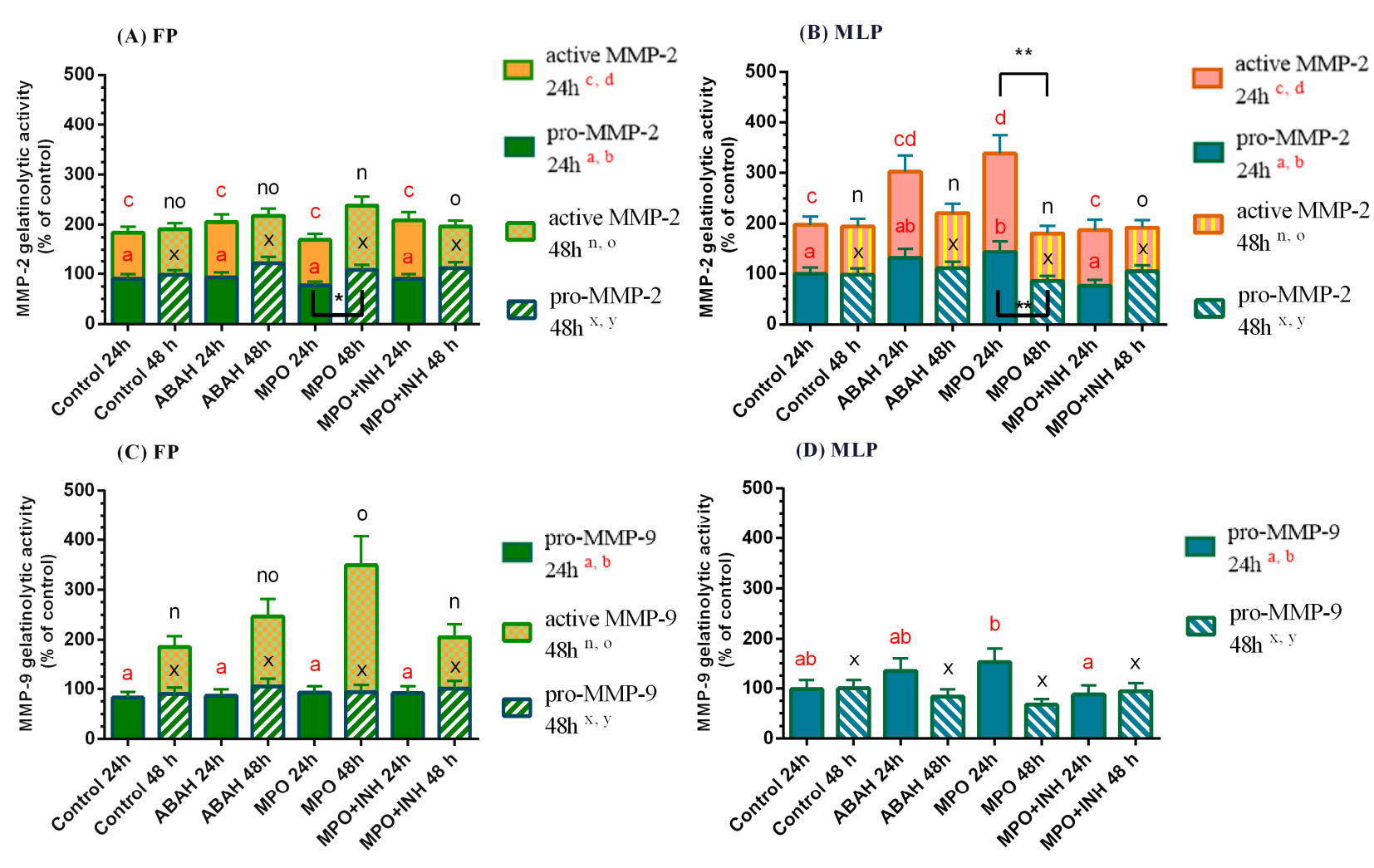

Figure 3. Relative MMP-2 (A,B) and MMP-9 (C,D) gelatinolytic activities in mare endometrial explants from the follicular phase (FP) and the mid-luteal phase (MLP) treated with culture medium only (Control), myeloperoxidase (MPO: $0.5 \mu \mathrm{g} / \mathrm{mL}$ ), 4-aminobenzoic hydrazide (ABAH: $10 \mu \mathrm{g} / \mathrm{mL})$, or MPO $(0.5 \mu \mathrm{g} / \mathrm{mL})+\mathrm{ABAH}(10 \mu \mathrm{g} / \mathrm{mL})$ for 24 or 48 h. Data of the least square means \pm SEM are shown in bars as percentage of change from control. Significance was determined at $p<0.05$. The differences among treatments with the same treatment time are signaled by distinct superscript letters. The differences among times of treatment for the identical treatment and MMP form are presented by asterisks $\left({ }^{*} p<0.05 ;{ }^{* *} p<0.01\right)$.

The COL1A2 transcripts increased in MPO treated explants in FP at $24 \mathrm{~h}$ and $48 \mathrm{~h}$ when related to the control group ( $p<0.0001 ; p<0.05$ respectively; Figure $1 \mathrm{~A})$, and to the ABAH-treated group $(p<0.0001 ; p<0.05$ respectively; Figure 1A). However, the use of MPO and ABAH treatments, when combined, impaired COL1A2 mRNA levels compared to the corresponding MPO-treated tissues (FP: $24 \mathrm{~h}-p<0.001 ; 48 \mathrm{~h}-p<0.01$; Figure 1A). In MLP endometrial explants treated for $24 \mathrm{~h}$, the MPO treatment lowered the transcription regarding the control group $(p<0.05$; Figure $1 \mathrm{~B})$. In FP endometrial explants treated with $\mathrm{MPO}$, COL1A2 transcription was higher at $24 \mathrm{~h}$ than at $48 \mathrm{~h}$ (Figure 1A). Nevertheless, in MLP explants the transcription was higher at $48 \mathrm{~h}$ compared to $24 \mathrm{~h}$ (Figure 1B) and also increased with $\mathrm{MPO}+\mathrm{ABAH}$ treatment (Figure 1B).

In MPO-treated explants, COL1 protein increased in the FP, both at $24 \mathrm{~h}(p<0.01$; Figure 1C) and $48 \mathrm{~h}(p<0.001$; Figure 1C); comparing to the control and ABAH groups, this only occurred during the longest treatment time $(p<0.0001$; Figure $1 \mathrm{C})$. The inhibitory effect of ABAH was detected in FP at $48 \mathrm{~h}$ regarding the group treated with $\mathrm{MPO}(p<0.01$; Figure 1C, Supplementary Material Figure S3). In the FP, COL1 protein relative abundance was greater in ABAH-treated explants at $24 \mathrm{~h}$ when compared to $48 \mathrm{~h}$ treatment (Figure 1C; Supplementary Material Figure S3). There were no differences in COL1 protein between treatments or treatment times in the MLP explants (Figure 1D).

\subsection{The Influence of $M P O$ and $A B A H$ on MMP Expression}

The transcription of $M M P 2$ was unchanged at both treatment times and estrous cycle phase (Figure 2A,B). In FP endometrial explants, at both treatment times, the transcript 
levels of $M M P 9$ increased in MPO treated groups relative to the corresponding non-treated explants $(p<0.01$; Figure $2 \mathrm{C})$ and to the ABAH-treated set $(24 \mathrm{~h}-p<0.0001 ; 48 \mathrm{~h}-p<0.01$; Figure 2C). However, the MPO + ABAH combined treatment reduced MMP9 mRNA compared to MPO-treated groups (FP: $24 \mathrm{~h}-p<0.01 ; 48 \mathrm{~h}-p<0.0001$; Figure 2C). The ABAH treatment decreased MMP-9 mRNA comparing to the non-treated group at $24 \mathrm{~h}$ in FP endometria $(p<0.05$; Figure 2C). In MLP tissues treated for $24 \mathrm{~h}$, all the treatments up-regulated MMP9 transcription relative to the control (ABAH $-p<0.05 ; \mathrm{MPO}$ and $\mathrm{MPO}+\mathrm{ABAH}-p<0.001$; Figure 2D). Moreover, the MPO and MPO + ABAH treatments increased MMP9 mRNA compared to the ABAH-treated group ( $p<0.001$; Figure 2D). At $48 \mathrm{~h}$, in MLP equine explants, all the treatments increased MMP9 transcript levels as well, compared to control tissues (ABAH— $p<0.01 ; \mathrm{MPO}-p<0.05$; $\mathrm{MPO}+\mathrm{ABAH}-p<0.0001$; Figure 2D). The $M M P 9$ transcription was higher in MLP tissues MPO-treated at $24 \mathrm{~h}$ than at $48 \mathrm{~h}$ (Figure 2D).

In FP explants at $48 \mathrm{~h}$, the MPO + ABAH treatment reduced gelatinolytic activity of activated MMP-2 in comparison to MPO-treated explants $(p<0.05$; Figure 3A; Supplementary Material Figure S3), which did not increase with respect to the control. The gelatinolytic activity of pro- $(p<0.05$; Figure 3B) and active ( $p<0.01$; Figure 3B) MMP-2 increased in MLP explants at $24 \mathrm{~h}$ with MPO treatment compared to control. However, the combined treatment of $\mathrm{MPO}+\mathrm{ABAH}$ reduced it in comparison to the MPO-treated group (pro-MMP-2: $p<0.01$; active MMP-2: $p<0.05$; Figure 3B; Supplementary Material Figure S3).

The pro-MMP-2 gelatinolytic activity increased at $48 \mathrm{~h}$ in FP with MPO treatment with respect to $24 \mathrm{~h}$ (Figure 3A), while in MLP both pro- and active MMP-2 gelatinolytic activities increased at $24 \mathrm{~h}$ relative to $48 \mathrm{~h}$ (Figure 3B; Supplementary Material Figure S3).

The MMP-9 active form gelatinolytic activity was only identified in FP at $48 \mathrm{~h}$ treatment, and MPO treatment up-regulated it compared to the control group $(p<0.01$; Figure 3C). Nevertheless, MPO $+\mathrm{ABAH}$ combination reduced the activity of active MMP-9, with respect to MPO-treated explants ( $p<0.01$; Figure 3C; Supplementary Material Figure S3). The analysis of pro-MMP-9 gelatinolytic activity showed its decrease after MPO + ABAH of MLP explant treatment for $24 \mathrm{~h}$ compared to MPO-treated explants $(p<0.05$; Figure 3D), which did not differ from its respective control.

The interactions found between treatments, estrous cycle phase, and time of treatment are listed in Supplementary Table S1. In Supplementary Table S2, the differences of the same treatments between the FP and MLP inside each treatment time are presented.

\section{Discussion}

Since the discovery that neutrophils release NETs secondary to the contact with bacteria [14] and semen $[12,13]$ in mare endometrium and that the enzymes found in NETs act as pro-fibrotic factors in mare endometrosis [18], we aimed to investigate if it would be feasible to reduce in vitro COL production induced by these enzymes by specifically inhibiting them [19-21]. In our study, MPO treatment elevated the transcripts of COL1A2 mRNA and COL1 relative protein abundance at both times of incubation only in FP equine endometria. It is in the FP, under the influence of estrogens, that the mare endometrium is more exposed to the invading bacteria, since the cervix is relaxed and open [51]. Nevertheless, it appears that mares with healthy endometria are capable of defeating bacteria during this phase of the estrous cycle. As such, after induced endometritis with Escherichia coli infusion, mares presented lower positive bacteriological cultures and neutrophil counts in endometrial swabs when infused at estrus, rather than at diestrus [52]. However, it is worth noting that it is in the FP that Streptococcus equi subspecies zooepidemicus (bacteria which cause endometritis in the mare) attach the most to mare endometria with endometrosis [53]. Nevertheless, in spite of the mechanisms for defeating bacteria during estrus, a study on gene expression in biopsies from healthy equine endometrium at different times of the estrous cycle showed that, in the FP, the transcription of COL1A1 increases until the ovulation day [54]. In contrast, in the luteal phase, gene expression of COL1A1 is lowered [54]. Similarly, in women, stromal endometrial cells treated in vitro with estrogen 
showed an increase in the deposition of collagen, while progesterone stimulation resulted in an increase in the breakdown of collagen [55]. These studies might explain why the MPO induced collagen response is only observed in the FP. These findings agree with Rebordão et al.'s work [18], where MPO elevated COL1 production in FP type I/IIA endometria. Some studies in other tissues also linked MPO to tissue damage. Human cystic fibrosis [56] and atrial fibrosis [57], as well as liver fibrosis in a mice model [27], have been associated with MPO-induced tissue injury. In addition, stellate cells from liver were activated by $\mathrm{MPO}$, leading to an in vitro up-regulation of COL1 via the fibrogenic factor TGF $\beta 1$ [27]. In equine endometrial explants [18,20] and fibroblasts [58], TGF $\beta 1$ was linked to endometrosis by increasing COL1 production. We postulated that MPO may also act via TGF $\beta 1$ in the equine endometrium.

The inhibitory action of ABAH on MPO-induced COL1 was detected in FP on mRNA expression at both times of treatment, and on protein relative abundance at the longest treatment time. We have shown for the first time to date that by inhibiting MPO in vitro, COL1 protein decreased in mare endometrium. Nonetheless, the ABAH mechanism of action is not yet well known. Some authors proposed a mechanism of action where $\mathrm{ABAH}$ is oxidized by $\mathrm{MPO}$ to a radical that reduces MPO to its ferrous intermediate by destroying the MPO heme group. Ferrous MPO reacts with hydrogen peroxide, thereby originating an irreversible inactivation [28,59]. However, data from in vitro studies cannot be directly extrapolated to in vivo treatments [60]. Nevertheless, in vitro systems are a faster approach to predict fibrogenic potential by monitoring the response to pro-fibrotic modulators [61]. Thus, the usage of $\mathrm{ABAH}$ as a prophylactic and/or therapeutic means for equine endometrial fibrosis needs further evaluation for its in vivo use.

The proteolysis of the ECM appears to be a crucial occurrence in the inflammatory process and, therefore, on the fibrotic process as well. Increased synthesis/deposition and decreased degradation of ECM components lead to fibrosis [62]. The MMPs are enzymes involved in this ECM turnover [31]. In equine explants, MMP-2 and MMP-9 secretion differed when challenged with cytokines and is dependent on the severity of endometrosis, which may link them to modifications in the endometrium that predispose to fibrosis development [37]. It was demonstrated that TGF $\beta 1$ treatment increased MMP-9 secretion in mare endometrial fibroblasts and epithelial cells and that the endometrial MMP expression changes at different categories of endometrosis [38]. In other tissues, the concomitant increased levels of MPO and MMP-2/-9 were also reported in rat temporomandibular joint inflammation [63], in inflamed human dental pulp tissue [64], and in fat meal induced endothelial damage in humans [65].

In our study, the activated MMP-2 gelatinolytic activity increased in MLP explants at $24 \mathrm{~h}$ in response to MPO treatment and was reduced with the treatment combination of $\mathrm{MPO}+\mathrm{ABAH}$. This may suggest that MMP-2 is implicated in an in vivo acute reaction to a MPO-induced inflammation in MLP endometria. In addition, MMP-9 active form gelatinolytic activity augmented with MPO treatment but was inhibited by ABAH at $48 \mathrm{~h}$ in FP endometrial explants. This could suggest MMP-9 participation, particularly, in FP, in a reaction to a continued exposure to $\mathrm{MPO}$.

In our previous in vitro works, in response to elastase treatment, MMPs' expression also differed according to the estrous cycle phase and treatment time, suggesting that the endometrial response is affected by hormonal variations and by the length of the stimulus [20]. Moreover, cathepsin G treatment increased MMPs gelatinolytic activity, mainly in follicular phase endometrial explants, and reduced with addition of a cathepsin $G$ inhibitor [21]. The MMPs' output differs and depends on the stimulus, phase of estrous cycle, and treatment duration. So, further in vitro and in vivo research is crucial to understand the action of MMPs in both healthy and fibrotic endometrium.

Therefore, future works should consider testing in vivo a combination of elastase, cathepsin G, and MPO inhibitors or the use of a single inhibitor capable of hindering all the pro-fibrotic effects of those enzymes found in NETs in mare endometrium. Based on this study, MMP-2 appears to be involved in a fast in vitro response to MPO treatment in MLP 
endometrial explants. In contrast, MMP-9 seems to be released by FP equine endometrial explants after a prolonged exposure to MPO.

\section{Conclusions}

Our findings reinforced the knowledge about MPO pro-fibrotic effects in equine endometrium. Myeloperoxidase induced COL1 and MMP-2/-9 activity in vitro in equine endometrium, and ABAH was shown to inhibit MPO-induced COL1 expression, as well as the activity of MMP-2/-9 induced by MPO. These data should be considered when studying endometrosis development and the attempt to fight this disease by inhibiting profibrotic enzymes found in NETs. However, caution should be taken by not extrapolating these in vitro study results on the use of $\mathrm{ABAH}$ as an in vivo therapeutic approach to prevent endometrosis.

Supplementary Materials: The following are available online at https:/ /www.mdpi.com/2076-261 5/11/1/208/s1: Figure S1: Activity of lactate dehydrogenase restrained in conditioned culture media of mare endometrial explants; Figure S2: Prostaglandin F2 $\alpha$ secretion by mare endometrial explants after oxytocin treatment; Table S1: Significance levels ( $p$ values) for 2-, 3-, and 4-way interactions among estrous cycle phases, treatment time, and myeloperoxidase or 4-aminobenzoic hydrazide treatments for the measured variables; Table S2: Differences of the same treatments between the follicular phase and mid-luteal phase inside each treatment time; Figure S3: Representative panels of collagen type I western blotting and pro and active forms of MMP-2 and MMP-9 zymograms in mare endometrium.

Author Contributions: Conceptualization, G.F.-D. and D.J.S.; methodology, A.A., C.F., M.R.R., A.S.M., K.L., and P.P.-B.; software, L.T.d.G.; validation, G.F.-D., D.J.S., M.R.R., A.S.-M., and L.T.d.G.; formal analysis, A.A., C.F., and L.T.d.G.; investigation, A.A., C.F., M.R.R., A.S.-M., K.L., and P.P.-B.; resources, G.F.-D. and D.J.S.; data curation, G.F.-D. and D.J.S.; writing — original draft preparation, A.A.; writing —review and editing, G.F.-D., D.J.S., A.S.-M., and M.R.R.; visualization, G.F.-D. and D.J.S.; supervision, G.F.-D. and D.J.S.; project administration, G.F.-D. and D.J.S.; funding acquisition, G.F.-D. and D.J.S. All authors have read and agreed to the published version of the manuscript.

Funding: The research was supported by the bilateral Polish-Portugal research project under the agreement of NAWA project (No. PPN/BIL/2018/1/00250/U/0001) and Fundação para a Ciência e Tecnologia (FCT) Projects (UIDB/00276/2020 and PTDC/CVT-REP/4202/2014). A.A. was supported by a Doctoral fellowship from Fundação para a Ciência e Tecnologia (SFRH/BD/101058/2014).

Institutional Review Board Statement: Not applicable.

Informed Consent Statement: Not applicable.

Data Availability Statement: No new data were created or analyzed in this study. Data sharing is not applicable to this article.

Acknowledgments: We are grateful to Paula Brito and Agnieszka Baclawska for assistance in the laboratory and Katarzyna Jankowska and Maria do Rosário Luís for preparing histological samples.

Conflicts of Interest: The authors declare no conflict of interest.

\section{References}

1. Nicholls, S.J.; Hazen, S.L. Myeloperoxidase and Cardiovascular Disease. ATVB 2005, 25, 1102-1111. [CrossRef]

2. Liu, W.-Q.; Zhang, Y.-Z.; Wu, Y.; Zhang, J.-J.; Li, T.-B.; Jiang, T.; Xiong, X.-M.; Luo, X.-J.; Ma, Q.-L.; Peng, J. MyeloperoxidaseDerived Hypochlorous Acid Promotes Ox-LDL-Induced Senescence of Endothelial Cells through a Mechanism Involving $\beta$-Catenin Signaling in Hyperlipidemia. Biochem. Biophys. Res. Commun. 2015, 467, 859-865. [CrossRef]

3. Klebanoff, S.J. Myeloperoxidase: Friend and Foe. J. Leukoc. Biol. 2005, 77, 598-625. [CrossRef]

4. Teng, T.-S.; Ji, A.; Ji, X.-Y.; Li, Y.-Z. Neutrophils and Immunity: From Bactericidal Action to Being Conquered. J. Immunol. Res. 2017, 2017, 1-14. [CrossRef]

5. Brinkmann, V. Neutrophil Extracellular Traps Kill Bacteria. Science 2004, 303, 1532-1535. [CrossRef] [PubMed]

6. Segal, A.W. How neutrophils kill microbes. Annu. Rev. Immunol. 2005, 23, 197-223. [CrossRef] [PubMed]

7. Nauseef, W.M. Myeloperoxidase in Human Neutrophil Host Defence: Myeloperoxidase in Human Neutrophil Host Defence. Cell Microbiol. 2014, 16, 1146-1155. [CrossRef] [PubMed] 
8. Kotilainen, T.; Huhtinen, M.; Katila, T. Sperm-Induced Leukocytosis in the Equine Uterus. Theriogenology 1994, 41, 629-636. [CrossRef]

9. Katila, T. Onset and Duration of Uterine Inflammatory Response of Mares after Insemination with Fresh Semen. Biol. Reprod. 1995, 52, 515-517. [CrossRef]

10. Troedsson, M.H.T.; Liu, I.K.M.; Thurmond, M. Function of Uterine and Blood-Derived Polymorphonuclear Neutrophils in Mares Susceptible and Resistant to Chronic Uterine Infection: Phagocytosis and Chemotaxis1. Biol. Reprod. 1993, 49, 507-514. [CrossRef]

11. Troedsson, M.H.T. Breeding-Induced Endometritis in Mares. Vet. Clin. North Am. Equine Pract. 2006, 22, 705-712. [CrossRef] [PubMed]

12. Alghamdi, A.S.; Foster, D.N. Seminal DNase Frees Spermatozoa Entangled in Neutrophil Extracellular Traps. Biol. Reprod 2005, 73, 1174-1181. [CrossRef] [PubMed]

13. Alghamdi, A.S.; Lovaas, B.J.; Bird, S.L.; Lamb, G.C.; Rendahl, A.K.; Taube, P.C.; Foster, D.N. Species-Specific Interaction of Seminal Plasma on Sperm-Neutrophil Binding. Anim. Reprod. Sci. 2009, 114, 331-344. [CrossRef] [PubMed]

14. Rebordão, M.R.; Carneiro, C.; Alexandre-Pires, G.; Brito, P.; Pereira, C.; Nunes, T.; Galvão, A.; Leitão, A.; Vilela, C.; Ferreira-Dias, G. Neutrophil Extracellular Traps Formation by Bacteria Causing Endometritis in the Mare. J. Reprod. Immunol. 2014, 106, 41-49. [CrossRef] [PubMed]

15. Manda, A.; Pruchniak, M.P.; Araźna, M.; Demkow, U.A. Neutrophil Extracellular Traps in Physiology and Pathology. Cent. Eur. J. Immunol. 2014, 1, 116-121. [CrossRef] [PubMed]

16. Parrilla-Hernandez, S.; Ponthier, J.; Franck, T.Y.; Serteyn, D.D.; Deleuze, S.C. High Concentrations of Myeloperoxidase in the Equine Uterus as an Indicator of Endometritis. Theriogenology 2014, 81, 936-940. [CrossRef]

17. Nazhat, S.A.; Kitahara, G.; Kozuka, N.; Mido, S.; Sadawy, M.; Ali, H.E.-S.; Osawa, T. Associations of Periparturient Plasma Biochemical Parameters, Endometrial Leukocyte Esterase and Myeloperoxidase, and Bacterial Detection with Clinical and Subclinical Endometritis in Postpartum Dairy Cows. J. Vet. Med. Sci. 2018, 80, 302-310. [CrossRef]

18. Rebordão, M.R.; Amaral, A.; Lukasik, K.; Szóstek-Mioduchowska, A.; Pinto-Bravo, P.; Galvão, A.; Skarzynski, D.J.; Ferreira-Dias, G. Constituents of Neutrophil Extracellular Traps Induce in Vitro Collagen Formation in Mare Endometrium. Theriogenology 2018, 113, 8-18. [CrossRef]

19. Amaral, A.; Fernandes, C.; Lukasik, K.; Szóstek-Mioduchowska, A.; Baclawska, A.; Rebordão, M.R.; Aguiar-Silva, J.; Pinto-Bravo, P.; Skarzynski, D.J.; Ferreira-Dias, G. Elastase Inhibition Affects Collagen Transcription and Prostaglandin Secretion in Mare Endometrium during the Estrous Cycle. Reprod. Dom. Anim. 2018, 53, 66-69. [CrossRef]

20. Amaral, A.; Fernandes, C.; Rebordão, M.R.; Szóstek-Mioduchowska, A.; Lukasik, K.; Gawronska-Kozak, B.; Telo da Gama, L.; Skarzynski, D.J.; Ferreira-Dias, G. The In Vitro Inhibitory Effect of Sivelestat on Elastase Induced Collagen and Metallopeptidase Expression in Equine Endometrium. Animals 2020, 10, 863. [CrossRef]

21. Amaral, A.; Fernandes, C.; Morazzo, S.; Rebordão, M.R.; Szóstek-Mioduchowska, A.; Lukasik, K.; Gawronska-Kozak, B.; Telo da Gama, L.; Skarzynski, D.J.; Ferreira-Dias, G. The Inhibition of Cathepsin G on Endometrial Explants With Endometrosis in the Mare. Front. Vet. Sci. 2020, 7, 582211. [CrossRef] [PubMed]

22. Kenney, R.M. The aetiology, diagnosis, and classification of chronic degenerative endometritis. In Workshop on Equine Endometritis; Hughes, J.P., Ed.; Newmarket Press: New York, NY, USA, 1992; Volume 125, p. 186.

23. Hoffmann, C.; Ellenberger, C.; Mattos, R.C.; Aupperle, H.; Dhein, S.; Stief, B.; Schoon, H.-A. The Equine Endometrosis: New Insights into the Pathogenesis. Anim. Reprod. Sci. 2009, 111, 261-278. [CrossRef] [PubMed]

24. Sagel, S.D.; Wagner, B.D.; Anthony, M.M.; Emmett, P.; Zemanick, E.T. Sputum Biomarkers of Inflammation and Lung Function Decline in Children with Cystic Fibrosis. Am. J. Respir. Crit. Care Med. 2012, 186, 857-865. [CrossRef] [PubMed]

25. Sly, P.D.; Gangell, C.L.; Chen, L.; Ware, R.S.; Ranganathan, S.; Mott, L.S.; Murray, C.P.; Stick, S.M. Risk Factors for Bronchiectasis in Children with Cystic Fibrosis. N. Engl. J. Med. 2013, 368, 1963-1970. [CrossRef] [PubMed]

26. Beard, M.R.; Jones, B.E. Hepatitis C Virus and Oxidative Stress: A Dangerous Liaison. Future Virol. 2006, 1, 223-232. [CrossRef]

27. Pulli, B.; Ali, M.; Iwamoto, Y.; Zeller, M.W.G.; Schob, S.; Linnoila, J.J.; Chen, J.W. Myeloperoxidase-Hepatocyte-Stellate Cell Cross Talk Promotes Hepatocyte Injury and Fibrosis in Experimental Nonalcoholic Steatohepatitis. Antioxid. Redox Signal. 2015, 23, 1255-1269. [CrossRef]

28. Kettle, A.J.; Gedye, C.A.; Winterbourn, C.C. Mechanism of Inactivation of Myeloperoxidase by 4-Aminobenzoic Acid Hydrazide. Biochem. J. 1997, 321, 503-508. [CrossRef]

29. Lazarević-Pasti, T.; Leskovac, A.; Vasić, V. Myeloperoxidase Inhibitors as Potential Drugs. Curr. Drug. Metab. 2015, 16, 168-190. [CrossRef]

30. Kim, H.; Wei, Y.; Lee, J.Y.; Wu, Y.; Zheng, Y.; Moskowitz, M.A.; Chen, J.W. Myeloperoxidase Inhibition Increases Neurogenesis after Ischemic Stroke. J. Pharmacol. Exp. Ther. 2016, 359, 262-272. [CrossRef]

31. Hair, P.S.; Sass, L.A.; Krishna, N.K.; Cunnion, K.M. Inhibition of Myeloperoxidase Activity in Cystic Fibrosis Sputum by Peptide Inhibitor of Complement C1 (PIC1). PLoS ONE 2017, 12, e0170203. [CrossRef]

32. Vandooren, J.; Van den Steen, P.E.; Opdenakker, G. Biochemistry and Molecular Biology of Gelatinase B or Matrix Metalloproteinase-9 (MMP-9): The next Decade. Crit. Rev. Biochem. Mol. Biol. 2013, 48, 222-272. [CrossRef]

33. Wang, X.; Khalil, R.A. Matrix Metalloproteinases, Vascular Remodeling, and Vascular Disease. In Advance Pharmacol; Elsevier: Amsterdam, The Netherlands, 2018; Volume 81, pp. 241-330. [CrossRef] 
34. Aresu, L.; Benali, S.; Giannuzzi, D.; Mantovani, R.; Castagnaro, M.; Falomo, M.E. The Role of Inflammation and Matrix Metalloproteinases in Equine Endometriosis. J. Vet. Sci. 2012, 13, 171. [CrossRef] [PubMed]

35. Centeno, L.A.M.; Bastos, H.B.A.; Bueno, V.L.C.; Trentin, J.M.; Fiorenza, M.F.; Fiala-Rechsteiner, S.; Kretzmann, N.A.; Mattos, R.C.; Rubin, M.I.B. Gene Expression of MMP-1, MMP-2 and TNF- $\alpha$ in the Endometrium of Mares With Different Degrees of Fibrosis. J. Equine Vet. Sci. 2018, 66, 143-144. [CrossRef]

36. Walter, I.; Handler, J.; Miller, I.; Aurich, C. Matrix metalloproteinase 2 (MMP-2) and tissue transglutaminase (TG 2) are expressed in periglandular fibrosis in horse mares with endometrosis. Histol. Histopathol. 2005, 20, 1105-1113. [CrossRef] [PubMed]

37. Szóstek-Mioduchowska, A.Z.; Baclawska, A.; Okuda, K.; Skarzynski, D.J. Effect of Proinflammatory Cytokines on Endometrial Collagen and Metallopeptidase Expression during the Course of Equine Endometrosis. Cytokine 2019, 123, 154767. [CrossRef] [PubMed]

38. Szóstek-Mioduchowska, A.; Słowińska, M.; Pacewicz, J.; Skarzynski, D.J.; Okuda, K. Matrix Metallopeptidase Expression and Modulation by Transforming Growth Factor-B1 in Equine Endometrosis. Sci. Rep. 2020, 10, 1119. [CrossRef] [PubMed]

39. Szóstek-Mioduchowska, A.Z.; Baclawska, A.; Rebordão, M.R.; Ferreira-Dias, G.; Skarzynski, D.J. Prostaglandins Effect on Matrix Metallopeptidases and Collagen in Mare Endometrial Fibroblasts. Theriogenology 2020, 153, 74-84. [CrossRef] [PubMed]

40. Roberto da Costa, R.P.; Ferreira-Dias, G.; Mateus, L.; Korzekwa, A.; Andronowska, A.; Platek, R.; Skarzynski, D.J. Endometrial Nitric Oxide Production and Nitric Oxide Synthases in the Equine Endometrium: Relationship with Microvascular Density during the Estrous Cycle. Domest. Anim. Endocrinol. 2007, 32, 287-302. [CrossRef]

41. Rebordão, M.R.; Amaral, A.; Lukasik, K.; Szóstek-Mioduchowska, A.; Pinto-Bravo, P.; Galvão, A.; Skarzynski, D.J.; Ferreira-Dias, G. Impairment of the Antifibrotic Prostaglandin E2 Pathway May Influence Neutrophil Extracellular Traps-Induced Fibrosis in the Mare Endometrium. Domest. Anim. Endocrinol. 2019, 67, 1-10. [CrossRef]

42. Kenney, R.M.; Doig, P.A. Equine endometrial biopsy. Current Therapy in Theriogenology 2: Diagnosis, Treatment, and Prevention of Reproductive Diseases in Small and Large Animals, 2nd ed.; David, A.M., Ed.; W.B. Saunders: Philadelphia, PA, USA, 1986; pp. 723-729.

43. Nash, D.; Lane, E.; Herath, S.; Martin Sheldon, I. Endometrial Explant Culture for Characterizing Equine Endometritis: Optimization of equine endometrial culture. Am. J. Reprod. Immunol. 2008, 59, 105-117. [CrossRef]

44. Szóstek, A.Z.; Lukasik, K.; Galvão, A.M.; Ferreira-Dias, G.M.; Skarzynski, D.J. Impairment of the Interleukin System in Equine Endometrium During the Course of Endometrosis1. Biol. Reprod. 2013, 89, 79. [CrossRef] [PubMed]

45. Forbes, L.V.; Sjögren, T.; Auchère, F.; Jenkins, D.W.; Thong, B.; Laughton, D.; Hemsley, P.; Pairaudeau, G.; Turner, R.; Eriksson, H.; et al. Potent Reversible Inhibition of Myeloperoxidase by Aromatic Hydroxamates. J. Biol. Chem. 2013, 288 , 36636-36647. [CrossRef] [PubMed]

46. Dheda, K.; Huggett, J.F.; Bustin, S.A.; Johnson, M.A.; Rook, G.; Zumla, A. Validation of Housekeeping Genes for Normalizing RNA Expression in Real-Time PCR. BioTechniques 2004, 37, 112-119. [CrossRef] [PubMed]

47. Zhao, S.; Fernald, R.D. Comprehensive Algorithm for Quantitative Real-Time Polymerase Chain Reaction. J. Comput. Biol. 2005, 12, 1047-1064. [CrossRef] [PubMed]

48. Posch, A.; Kohn, J.; Oh, K.; Hammond, M.; Liu, N. V3 Stain-Free Workflow for a Practical, Convenient, and Reliable Total Protein Loading Control in Western Blotting. J. Vis. Exp. 2013, 82, e50948. [CrossRef] [PubMed]

49. Manuel, J.A.; Gawronska-Kozak, B. Matrix Metalloproteinase 9 (MMP-9) Is Upregulated during Scarless Wound Healing in Athymic Nude Mice. Matrix Biol. 2006, 25, 505-514. [CrossRef] [PubMed]

50. Raykin, J.; Snider, E.; Bheri, S.; Mulvihill, J.; Ethier, C.R. A Modified Gelatin Zymography Technique Incorporating Total Protein Normalization. Anal. Biochem. 2017, 521, 8-10. [CrossRef]

51. Aurich, C. Reproductive Cycles of Horses. Anim. Reprod. Sci. 2011, 124, 220-228. [CrossRef]

52. Marth, C.D.; Firestone, S.M.; Glenton, L.Y.; Browning, G.F.; Young, N.D.; Krekeler, N. Oestrous Cycle-Dependent Equine Uterine Immune Response to Induced Infectious Endometritis. Vet. Res. 2016, 47, 110. [CrossRef]

53. Ferreira-Dias, G.; Nequin, L.G.; King, S.S. Influence of Estrous Cycle Stage on Adhesion of Streptococcus Zooepidemicus to Equine Endometrium. Am. J. Vet. Res. 1994, 55, 1028-1031.

54. Gebhardt, S.; Merkl, M.; Herbach, N.; Wanke, R.; Handler, J.; Bauersachs, S. Exploration of Global Gene Expression Changes During the Estrous Cycle in Equine Endometrium1. Biol. Reprod. 2012, 87, 136. [CrossRef] [PubMed]

55. Stenbäck, F. Collagen Type III Formation and Distribution in the Uterus: Effects of Hormones and Neoplasm Development. Oncology 1989, 46, 326-334. [CrossRef] [PubMed]

56. Chandler, J.D.; Margaroli, C.; Horati, H.; Kilgore, M.B.; Veltman, M.; Liu, H.K.; Taurone, A.J.; Peng, L.; Guglani, L.; Uppal, K.; et al. Myeloperoxidase Oxidation of Methionine Associates with Early Cystic Fibrosis Lung Disease. Eur. Respir. J. 2018, 52, 1801118. [CrossRef] [PubMed]

57. Friedrichs, K.; Baldus, S.; Klinke, A. Fibrosis in Atrial Fibrillation-Role of Reactive Species and MPO. Front. Physio. 2012, 3, 214. [CrossRef] [PubMed]

58. Szóstek-Mioduchowska, A.Z.; Lukasik, K.; Skarzynski, D.J.; Okuda, K. Effect of Transforming Growth Factor -B1 on $\alpha$-Smooth Muscle Actin and Collagen Expression in Equine Endometrial Fibroblasts. Theriogenology 2019, 124, 9-17. [CrossRef] [PubMed]

59. Burner, U.; Obinger, C.; Paumann, M.; Furtmüller, P.G.; Kettle, A.J. Transient and Steady-State Kinetics of the Oxidation of Substituted Benzoic Acid Hydrazides by Myeloperoxidase. J. Biol. Chem. 1999, 274, 9494-9502. [CrossRef] [PubMed] 
60. Fabian, E.; Gomes, C.; Birk, B.; Williford, T.; Hernandez, T.R.; Haase, C.; Zbranek, R.; van Ravenzwaay, B.; Landsiedel, R. In Vitro-to-in Vivo Extrapolation (IVIVE) by PBTK Modeling for Animal-Free Risk Assessment Approaches of Potential EndocrineDisrupting Compounds. Arch. Toxicol. 2019, 93, 401-416. [CrossRef]

61. Clippinger, A.J.; Ahluwalia, A.; Allen, D.; Bonner, J.C.; Casey, W.; Castranova, V.; David, R.M.; Halappanavar, S.; Hotchkiss, J.A.; Jarabek, A.M.; et al. Expert Consensus on an in Vitro Approach to Assess Pulmonary Fibrogenic Potential of Aerosolized Nanomaterials. Arch. Toxicol. 2016, 90, 1769-1783. [CrossRef]

62. Harvey, A.; Montezano, A.C.; Lopes, R.A.; Rios, F.; Touyz, R.M. Vascular Fibrosis in Aging and Hypertension: Molecular Mechanisms and Clinical Implications. Can. J. Cardiol. 2016, 32, 659-668. [CrossRef]

63. Nascimento, G.C.; Rizzi, E.; Gerlach, R.F.; Leite-Panissi, C.R.A. Expression of MMP-2 and MMP-9 in the Rat Trigeminal Ganglion during the Development of Temporomandibular Joint Inflammation. Braz. J. Med. Biol. Res. 2013, 46, 956-967. [CrossRef]

64. Accorsi-Mendonça, T.; Silva, E.J.N.L.; Marcaccini, A.M.; Gerlach, R.F.; Duarte, K.M.R.; Pardo, A.P.S.; Line, S.R.P.; Zaia, A.A. Evaluation of Gelatinases, Tissue Inhibitor of Matrix Metalloproteinase-2, and Myeloperoxidase Protein in Healthy and Inflamed Human Dental Pulp Tissue. J. Endod. 2013, 39, 879-882. [CrossRef] [PubMed]

65. Spallarossa, P.; Garibaldi, S.; Barisione, C.; Ghigliotti, G.; Altieri, P.; Tracchi, I.; Fabbi, P.; Barsotti, A.; Brunelli, C. Postprandial Serum Induces Apoptosis in Endothelial Cells: Role of Polymorphonuclear-Derived Myeloperoxidase and Metalloproteinase-9 Activity. Atherosclerosis 2008, 198, 458-467. [CrossRef] [PubMed] 